\title{
Production And Marketing Network Chain of Brick Kiln Product: A CASE STUdy OF HYDERABAD CITY
}

\author{
Siriman.Naveen \\ School Of Economics, University Of Hyderabad
}

\begin{abstract}
Traditional Indian clay and mud brick kilns have been contributing a lot to the construction sector in general, real estate sector particularly since ages. This sector has been expanding day by day due rapid growth of population, real estate sector. The Indian traditional brick is product of unorganized sector and depending on the labour intensive based production system. This sector has been providing employment to the millions of people, but knows for violation of the fundamental right of labourers. Brick, being one of the oldest building materials, is extensively used as a main input in construction because of its durability, strength, reliability, low cost and easy availability. The brick kiln industries have to face the different kind hurdle in the process of production to marketing. The international organizations and government of India have initiated the several development programmes in ordered to upgrade the production efficiency of brick industry and to reduce pollution generated from the brick industry. From the inception of the brick kiln product to final consumption, various actors involve and many actors influence from inside and outside of the production process. Since this is an informal sector in nature in developing countries, it faces the several problems along the chain, it has the several links.
\end{abstract}

The present paper mainly explains the different stages and actors along the network chain of the brick kiln product market who influence the production at different stages directly or indirectly. The objectives of the paper are:

(1) Study the present state of brick kilns and different type of development programmes by government and non-government organizations. (2) Understand the brick kiln chain means how the product of traditional brick kilns reaches to the final consumer by the different agents in the markets along the market network chain from the inception of production process to marketing the product to final consumer and hurdles face by the each stage of the product.

\section{KEY WORDS}

traditional brick kilns, , agents, valve chains, network chains, unorganized sector, labour intensive, production process, upgrade.

\section{INTRODUCTION}

The word 'brick' originated in late middle English: from Middle Low German, Middle Dutch 'bricke', probably reinforced by Old French 'brique', of unknown origin or 'briquette', which means a block of compressed coal dust or peat used as fuel-origin late 19th century: French 
diminutive of brique brick. ${ }^{1}$ The antiquity of bricks can be pushed back to the ancient times. In Sanskrit it was known as 'Aishtakam'. Brick industry is the oldest industry in the history of mankind, it can be said that it is only manmade material that has defied time gracefully even though it was invented 5000 years ago. It is reported that hand dried, sun-dried mud bricks were made and used during the pre-pottery Neolithic period way back 10000B.C. ${ }^{2}$ Ever since man realized the housing as basic need, he started using bricks in various forms like green bricks, and sun dried bricks and the fired bricks.

\section{REVIEW OF LITERATURE}

The concept of the network chain or value chain described and developed by the Michael porter in his famous work comparative advantages (1985): creating and sustaining superior performance and latter it has been developed by the Garry Gereffi, John Humphrey, Kaplinsky, and Mike Morris etc. The value chain is concept and frame work for organizing and analyzing information on how input and services are brought together and then used to grow , transform , manufacture a product how the product then moves physically from the producer to final consumer how the value is increased along chain. The value chain consists of the links. A line is an actor employed in any of the relevant activities required in the chain.

According to the Mike Morris the value chain describes the full range of activities which are required to bring a product or service from conception, through the different phases of production (involving a combination of physical transformation and the input of various producer services), delivery to final consumers, and final disposal after use.

Kaplinsky (2000) describes value chain as a full range of activities which are required to bring a product or service passing through intermediate phase of production to delivery to consumer's final disposal after use.

Mowen and Hansen (2011, p.27) describes the value chain as "set of activities required to design, develop, produce, market, deliver and provide post-sales service for the product and services sold to the customer." According to Mowen and Hansen (2011), internal value chains exist which also need to be managed.

The Brick industry consists the many chains from owner(producer) of the brick kiln to final consumer, the Indian brick industry is the second largest producer in the world after the china as per the 2009 estimates production is increasing annually 5-10 percentages due to rapid expansion of the urbanization, infrastructure and housing sector. India estimated to have more than 145000 registered and unregistered brick kiln producing more than 236 billion bricks. The main cost components of these industries are labour, coal, land, mud, rent and electricity; it is the largest consumer of coal after the power and thermal sector, it consumes around 25 million tons every year. Brick kilns owners do not have a choice to access the institutional finance most of the finance operation out of own money, family saving, borrowing from relatives, friends and private money lenders.

\footnotetext{
${ }^{1}$ The New Oxford English dictionary, III Impression, London, 2001, pp.224-225.

${ }^{2}$ http://www.brickindia.com
} 
International Journal of Managing Value and Supply Chains (IJMVSC) Vol. 7, No. 1, March 2016

$12^{\text {th }}$ Planning commission also noticed the importance of infrastructure development and allocated large amount for it and the construction sector also expanding rapidly (annual growth rate 9 percentage) due to population pleasure and urbanization, these circumstances have been leading to rapid expansion of the brick kilns. But these most brick kilns are running in small scale unorganized sector, brick industry is the back bone of the infrastructure and construction sector, construction sector contributing 10 percentage to the GDP and growing at 9percentage every year. Studieson the brick kilns are showing that these industries has been using exploitative methods and violation of the laws are common feature of these industries, it is a seasonal activity begins in December and end in June.

Some of the studies showed that owner of the brick kiln are shut downing their kilns due to high interest rates on initial capital, rent on land and lack of input like mud and advances payment and labour demands more advances at the time of scarcity of labour but some studies shows lack of trust and indirect connection between workers and owners are the main reasons for the demanding advance payments. Its production activities cannot possible in rainy season, these industries have to reach target with in time. The time constrain on the brick kiln production is motivating owners of kilns to resort the exploitative method and using the exploitative method to get more profit, they pay wages which are less than the minimum wages, child labour, harassment, long working hours, violation of environment law , interstate migration law, human rights are common feature of these industries. And producer side studies shows that owner of the brick kilns are facing the problems like lack of access to the formal credit 90percentage of the owner depends on the informal credit which charge high interest rate on the capital, some studies shows 30percentage workers not bound to the contract, they left the work in middle.

\section{RESEARCH QUESTIONS AND GAP}

Brick is one of the main component of construction sector especially mud brick kilns have been contributing a lot to the human development since ages but in the context of the expanding nature of the real estate sector, construction agencies are leaning toward the light weight, different shapes, quality bricks which made by modern brick kilns or capital intensive industries. Traditional brick kilns sector are especially in developing countries like India, Pakistan, and Bangladesh is still manufacturing through the old techniques. In this scenario, an expanding real estate sector is dealing with theold technique used labour intensive technique based product and modern technique used and capital intensive based product. Here most of the high valued construction agencies are preferring the modern technique used capital intensive product, old technique used labour intensive product is using by low valued construction agencies. The rapid expansion of the real estate sector has been not fully absorbing the brick kilns product, it led to the change in the network chain of the traditional brick kiln product. Since this industry consider as an informal sector, it has been facing many problems and actors (internally and externally) along the chain. In this content the research need to address the several questions such as who are the different actors along the chain? What is the relationship between the actors? Who influences the chain internally and externally? Who does it impact the productivity of the brick kilns? What is risk involved along the chain and among different actors? What are different development programme by government and nongovernment organization to enhance the productivity of the brick kilns? And this study is most important and needs immediate attention because studies on brick kilns are mostly concentrated on labour and producer side only, but not on the value chain of the brick kiln. This study conducted on the Hyderabad, since the real estate sector of this city 
has been expanding rapidly, it led to expansion of the brick kiln sector, and brick kilns employees nearly 4 lakh people.

\section{Methodology}

This study is systematic and expressive in form and mainly focuses on the Production and marketing network chain of brick kiln product. This study has depended on the primary sources and secondary sources; emphasis was given more to the primary study. The primary data collection has been done by using both; a structured questionnaire for each of the respondent category and the interview method. The total sample size is 35 . The various samples or respondents related to the study were interviewed. For the purpose of Fthe data collection, the study used was the structured questionnaire. The total sample size can be divided broadly into three categories; The total sample size can be divided broadly into three categories; first set sample size is fifteen (15), which contains owner of brick kilns, second set of sample size is nine (9), taken from Attapur adda randomly which contains suppliers, dealers, the third set of sample size is eleven (11) have taken from different parts of Hyderabad relating to construction agencies which are using traditional mud and clay bricks.

Table 4.1: Sample design of owners of brick kiln

\begin{tabular}{|l|l|}
\hline Type of samples & Number of sample \\
\hline Owner of brick kiln & 15 \\
\hline
\end{tabular}

Table 4.2: Sample design of Attapur Adda

\begin{tabular}{|l|l|}
\hline Type of samples & Number of sample \\
\hline Suppliers & 6 \\
\hline Dealers & 3 \\
\hline Total & 9 \\
\hline
\end{tabular}

To find out the market chaim of brick kiln product, and to identify the different actors within and their relation, risk, scale of operation and quality determination of product; Attapur Adda was taken as case study. Here for this study a total size of nine (9) samples were taken; out of them six (6) are suppliers and three are (3) dealers.

Table 4.3: sample designed of clay brick using construction agencies

\begin{tabular}{|l|l|}
\hline Types of sample & Number of sample \\
\hline Residential construction & 9 \\
\hline Public utility constructions & 2 \\
\hline Total & 11 \\
\hline
\end{tabular}

For the study, a sample size of eleven (11) construction agencies were taken, which have been using mud and clay brick. Out of them nine (9) are residential construction project and two are public utility construction projects. 


\section{Data Source}

Both primary and secondary data have been used for the study, important respondents of the study are suppliers, dealers in Adda, supervisors, owners of the construction projects and individual house construction owners. The questions of the survey include open- ended as well as closed-end questions and a structured questionnaire schedule, designed for each of the respondents. The various reports, journals and news also have been taken into consideration, such as brick kiln reports of Eco Brick, clear air task force, UNDP-GEF Project, Cush man \& Wake Field, Knight Frank, Andhra Pradesh real estate association, KMPG and CRISEL.

\section{BRICK KILNS- GLOBAL SCENARIO}

Brick has been in use as main construction material all over the world in every class and kind of building. As per the 2007, estimates of Clean Air task Force production, the brick production has been dominated by few Asian countries such as China, India, Pakistan and Bangladesh. China had occupied the first place with 54percentage of the total production, India was in second with 11 percentage, Pakistan in third place with 8percentage and Bangladesh in the fourth place with 4percentage of total production. The recent year 2015 estimates of Anil Agarwal (Center for Science and Environment) shows that there has been an increase in overall production of the brick.

Table: 6.1.Global brick production

\begin{tabular}{|l|l|l|}
\hline Country & $\begin{array}{l}\text { Production } \\
\text { percentage }\end{array}$ & Billion Per annum \\
\hline China & $66.6 \%$ & 1000 \\
\hline India & $13.33 \%$ & 200 \\
\hline Pakistan & $3.00 \%$ & 45 \\
\hline Vietnam & $0.40 \%$ & 25 \\
\hline Bangladesh & $1.13 \%$ & 17 \\
\hline Nepal & $0.40 \%$ & 7 \\
\hline Rest of Asia & $0.47 \%$ & 6 \\
\hline Total Asia & $86.67 \%$ & 13,00 \\
\hline UK & $53.00 \%$ & 8 \\
\hline US & $37.00 \%$ & 4 \\
\hline Australia & $13.00 \%$ & 2 \\
\hline Rest of World & $12.40 \%$ & 186 \\
\hline Total Rest of World & $13.33 \%$ & 200 \\
\hline Total production & $100.00 \%$ & 1,500 \\
\hline
\end{tabular}

\section{Source: Anil Agarwal 2015: overview of Brick Kiln Industry Pollutions and Technology where we need to go?}

The table above clearly shows that brick kiln production has been expanding rapidly in China and India; there was 12.6 percentageincreases in the production of brick in China of total world production, which is 800 to 1000 billion, where as in case of India it increased to 2.33 
percentages, which is almost 140 billion to 200 billion brick production. The Asia's overall production has increased from almost 77percentagesto 86.67 percentage of total production.

\section{BRICK KILN-INDIAN SCENARIO}

Indian Brick Kiln industry is the second largest producer in the world after china, as per the 2009 estimates production has been increasing annually from 5-10percentage due to rapid expansion of the urbanization and real estate sector. India estimated to have more than 145000 registered and unregistered brick kilns; producing more than 236 billion bricks. ${ }^{3}$ The main cost components of these industries are labour, coal, land, mud, rent and electricity; since it is the largest consumer of coal after the power and thermal sector, it is consuming around 25 million tons every year. Indian brick kilns expanded their capacity of production from 140 billion in 2007 to 200 billion in 2015, almost 13.33percentages in the total world production. It consumes 350 billion tons of clay; employing 10 million people, which is twice to the China's brick kiln but ten times lower than the China's employee production capacity.

\section{HYDERABAD BRICK KILNS}

Hyderabad brick kilns are providing employment opportunities to nearly 4 lakh people, they are migrates from various states; especially most of them are Odhisa. These brick kiln are situated at the outskirts and rural urban places around the city. Hyderabad brick kiln are well reputed for violation of laws similar to other states' brick kilns. The average production of the brick workers varies around 700 to 1000 . The lack of employment opportunities at home, poverty and debt are pushing them to brick kilns. Hyderabad brick kilns are following advance payment system; making most of the labour in the end empty handed. These workers are brought in from the districts of western Odisha by a large network of contractors under conditions of bondage and semi bondage. These workers face severe exploitation; being paid a meager of Rs.200 for 1000 bricks, whereas the minimum rate set by government being Rs.387; they experience inhuman working hours from 4 a.m. to 8 p.m. Child labour, physical and sexual harassment is rampant. In addition to these, abolition of fundamental rights at work such as, social securities act and right to life with dignity, right to assemble, right to unionize, right to protection against violence is the common feature of this industry.

\section{DEVELOPMENT PROGRAMS IN INDIAN BRICK KILN INDUSTRY}

Despite brick industry's huge contribution to real estate sector, employment, role in urbanization, impact on health and environment, it had experienced some development programmes in order to reduce environmental damages, upgraded the technologies to increase the efficiency and production of brick kiln. The important government involvements were; the environmental regulations legislated in the 1990's, which led to upgradation in the firing technology from moving chimney bull trench kilns to fixed chimney bull trench kilns.

\footnotetext{
${ }^{3}$ http://pscst.gov.in/pscstHTML/brick.html
} 
International Journal of Managing Value and Supply Chains (IJMVSC) Vol. 7, No. 1, March 2016

Table: 9.1 Development Programmes in Indian Brick Industry

\begin{tabular}{|c|c|c|c|}
\hline Year & Agency & $\begin{array}{l}\text { Type of development } \\
\text { involvement }\end{array}$ & Result \\
\hline 1970s & $\begin{array}{l}\mathrm{CBRI}^{4} \text { of Govt } \\
\text { of India }\end{array}$ & $\begin{array}{l}\text { Initiated technical } \\
\text { development program by } \\
\text { introduction of zigzag } \\
\text { firing technology and semi } \\
\text { mechanization process }\end{array}$ & $\begin{array}{l}\text { 1. No large-scale implementation. } \\
2 . \text { But succeeded in planting } \\
\text { technologies }\end{array}$ \\
\hline 1990s & $\mathrm{CPCB} / \mathrm{MoEF}^{5}$ & $\begin{array}{llr}\text { Enacted regulations } & \text { to } \\
\text { control emissions } & \text { from } \\
\text { brick kilns } & & \end{array}$ & $\begin{array}{l}\text { Around } 30,000 \text { moving chimney } \\
\text { bull trench kilns technology } \\
\text { followed brick kilns shifted to more } \\
\text { efficient technology used fixed bull } \\
\text { trench chimney technology. }\end{array}$ \\
\hline 1990-2004 & $\begin{array}{l}\text { Swiss agency } \\
\text { for } \\
\text { development } \\
\text { and cooperation }\end{array}$ & $\begin{array}{l}\text { Initiated technical } \\
\text { development program } \\
\text { VSBK }^{6}\end{array}$ & $\begin{array}{l}\text { 1.No large-scale implementation. } \\
\text { 2.But succeeded in planting } \\
\text { technologies }\end{array}$ \\
\hline In 2009 & UNDP-GEP $^{7}$ & $\begin{array}{l}\text { Initiated technical } \\
\text { development by introducing } \\
\text { efficient bricks such as } \\
\text { Hollow bricks }\end{array}$ & Not known \\
\hline
\end{tabular}

Source: Greentech Knowledge Solutions Analysis, pg. no, 06.

\section{DifFERENT STAGES AND GOVERNANCE ALONG THE CLAY BRICK NETWORK CHAIN.}

\section{Map 10.1: Different Stages and Governance Along The Clay Brick Network Chain.}

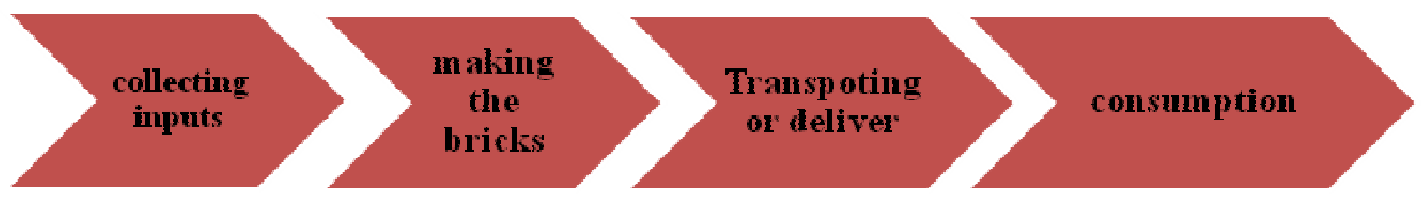

\section{Source: primary study.}

\footnotetext{
${ }^{4}$ Central Building Regulating Institution, Government of India.

${ }^{5}$ Central Pollution Control Board / Ministry of Environment and Forest.

${ }^{6}$ Vertical Shaft Brick Kilns.

${ }^{7}$ United state Development Program-Global Environment Facility.
} 
Production and Marketing Networks Chain definition generally explains how the products reach to the final consumer from raw material or initial stage of a product or service to intermediate stage and how the product is supplied to the final consumer. The brick kiln networks chain starts with the mobilization of the inputs which are required for the production of bricks. Clay, labour, coal, husk, land are the main inputs. Immediately after this mobilization phase, the second stage is manufacturing bricks, which includes the activities like mixing smooth clay with water, molding clay into shape, dying the wet bricks and arranging in a kiln and installation is provided with a mud pack, fired holes are left to ignite the kiln and are later sealed to keep the heat inside and burnt bricks are eventually separated.

The burnt bricks are transported either directly to the final consumers or through actors like suppliers and dealers, Suppliers and dealers are not the final consumers, these are intermediary traders. The final consumers in case of the brick kilns are individual house constructions and construction agencies which construct residential, commercial construction and other buildings.

The question of governance emerges when the actors along the chain act according to rules set by others like Government, NGOs, labour unions and Human Rights Forums etc. These are governed in two ways, some of them influence from outside (external governance) and some from within the chain (internal governance). Brick kiln chains get influenced and affected by different actors along the chain from production to final consumer. At the stage of inception the brick kiln has to encounter the environment laws to reduce pollution and land erosion.

In the process, Kilns need to satisfy the labour laws such as minimum wages, inter-state migrant workmen Act, child labour Act etc., which govern the production process of the brick kilns. Apart from this legal governance, other agencies like NGOs, human rights forums and labour unions also influence the chain at the stages of clay brick making and transportation. The studies on the mud and clay brick industries show that these laws are not being adhered to by the mud and clay brick productions and at every stage these laws are being violated by kilns.

The final stage of clay brick is consumption, starts with the examination of minimum quality standards of clay bricks through the crude methods of quality checking such as random checking, dropping the product from height, they take colour also into consideration, believing that the more red in colour the brick is, more is the quality of the brick and accurate methods such as lab testing and quality check by machine. Other important links in the chain are fear of losing costumers, which is always used as weapon by construction agencies leading to supply of quality product at desired price and on time delivery of consignment. Informal contract between them generally does not ensure legal claim on contract, but trust and long term relations play key role in the sustenance of these network relations for over a long period of time.

The fact that construction agencies do not regulate the manufacturing practices of the brick kilns from where these agencies source their bricks from. The construction agencies therefore are not concerned about the working conditions in the brick kilns, what they are focused on is the quality of the bricks and on time delivery of the product. Brick kilns have to produce quickly to deliver the consignment on time, this pressure in fact makes working conditions more vulnerable for the labour and increases the number of working hours indirectly. All the kilns deliver the consignment on time and seldom delay. The delay in payment also influences the worker's conditions indirectly. From big construction agencies like Nagarjuna and Adithya to small builders like Sri Sai Krupa avenues all the construction agencies delay the payments to the brick 
kilns and it therefore influences the brick kiln owner's capacity to pay the workers' net wages towards the end of the season. ${ }^{8}$

The delayed payment to consignment is not received at once; rather it is received under installments. There is no a priori information available with the brick kiln producer along the network chain from the construction agency about the quantity of bricks required. However, as a consequence to long term network relations, the average quantity of demand is anticipated by the brick kiln owners based on their experience. The kilns are generally informed of what is the total requirement of bricks for the project at the beginning of the construction project. However, this requirement assessment is not a statement of assured demand for the brick kilns. Construction agencies do not depend on the single clay brick kiln for its supply therefore how much it will actually buy from brick kiln is then left to other dynamics like quality and time lines. Every brick kiln informs their capability of supplying brick stock. The brick kiln producers on the other hand do not depend on the single consumer either, therefore the construction agency does not have an assured supply. It is amidst these uncertainties that trust formation and networks have to emerge and sustain in these markets.

\section{UPGRADING AND RELATIONSHIP BETWEEN CLAY BRICK KILN AND CONSTRUCTION AGENCIES}

Generally the value chain literature explains possibilities of upgrading the product and actors along the chain. The ILO value chain frame works explains that upgrading in the value chain leads to decent work conditions along the chain. The dominant feature of the Indian clay brick industry is that it employs the labour, who are distressed and migrated and common elements of these labourers are indebtedness, illiteracy, poverty and unemployment at the native place. These clay kilns are known for their indecent working conditions, low wages, and excessive hours of work, low hourly pay, child labour, sexual harassment, and gender inequality, lack of bargaining power, no union, and no voice at work place, use of threat and violence, verbal abuse, hazardous working conditions and no basic amenities in the living conditions.

Even though there is no formal long term contract between the construction agencies and owners of the brick kiln, relation between them is informal but long term. Most of the agencies always try to maintain the long term contact with the kilns, which give them an advantage of more delay in payment, get quality bricks at low price. But this long term relationship between them generally has to induce for upgrading the quality product and according to the ILO frame work long term relation between the formal sector and informal sector supposed to provide decent work conditions in informal sector because these informal sectors are directly contributing to the formal sectors growth. In reality these construction agencies are ever interested in the up gradation of the quality of the bricks, technologies in bricks making only. These construction agencies do not care how the bricks are made and at what circumstances, they have only contacts with the owner of the kiln and ever concern the conditions of the work in the brick kilns.

\footnotetext{
${ }^{8}$ The Nagarjuna, Adithya Construction Agencies are the top and well established construction agencies in Hyderabad and Sri Sai Krupa Avenues is small construction agencies in term of investment it put in present construction project. These were from the samples having collected from the random snow ball method.
} 
International Journal of Managing Value and Supply Chains (IJMVSC) Vol. 7, No. 1, March 2016

\section{CONCLUSION}

Indian brick kilns have been expanding rapidly and contributing a lot to the economy but the study of network chain or value chain of the brick kilns in India generally, particularly in Hyderabad clarifies that from the inception of the production to final consumption of brick, there are many actors involve such as owners of brick kiln, labour of brick production, middle man between owner of brick kiln and labour. Once the product made the product goes to the final consumer in different ways, it can be reached through the supplier, who buy product from owner of kilns but in small quantity sell it in $\mathrm{Adda}^{9}$.Next actor along the chain is dealer who has permanent place to sell the product of brick kilns, he sells brick and other construction materials too but small quantity, final consumer can also get product directly from owner of brick kiln or other. Small construction agencies and individual constructions only depend on suppliers and dealers, big constructions agencies have the direct connection with the owner of brick kilns.

In production process owner of brick has to face many actors (internal and external governance)such as labour unions, human right forum, NGO and other government bodies, since these kilns are well known for violation of rule. According to the ILO value chains literature, when there is a relation between informal and formal sectors in production process, it leads to betterment of working conditions of the informal sector but in case of brick kilns revers have been witnessed. Brick kilns are facing many problems at market side and production side in orderto overcome these all upgrading in technology and government intervention is necessary.

\section{REFERENCES}

[1] Anni-Kaisa Kahkonen, Katrina Lintukangas (2012), "Supply management as a value creating element in a firm”, International Journal of Value Chain Management, 2012, Vol. 6, No. 4, pp.358-374.

[2] Anil Agarwal. (2015). Overview of Brick Kiln Industry Pollutions and Technology where we need to go? Center for science and Environment.

[3] AyodejiEmmanuel, Oke, Douglas Omoregie, Aghimien and Samuel Olusola, Olatunji.(2015).IMPLEMENTATION OF VALUE MANAGEMENT AS AN ECONOMIC SUSTAINABILITY TOOL FOR BUILDING CONSTRUCTION IN NIGERIA. International Journal of Managing Value and Supply Chains (IJMVSC). Vol. 6, No. 4.

[4] Backstrand, J. and Safsten, K. (2006), Supply Chain Interaction - Market requirements affecting the level of interaction, Proceedings from the 15th Annual IPSERA Conference 2006, San Diego, USA

[5] Baum, Ellen. (2010). Black Carbon from Brick Kiln.

[6] Bhukuth Augendra, Parthasarthy, Venkatasubramaian (2007) Labour in brick kiln -case study in Chennai Guerin Isabelle. Economic and political weekly.

[7] Cooper, M. C., Lambert, D. M. and Pagh, J. D. (1997), "Supply Chain Management: More than a New Name for Logistics”, International Journal of Logistics Management.

\footnotetext{
${ }^{9}$ Adda means generally a place, where people gather for conversation and a junction point for public transport use. But here Adda can be defined as the place where the suppliers of the bricks come together and sell their stock or brick to different consumers, be it for the individuals constructing houses, construction agencies or dealer.
} 
International Journal of Managing Value and Supply Chains (IJMVSC) Vol. 7, No. 1, March 2016

[8] Gereffi, G. (1994), "The Organization of Buyer-Driven Global Commodity Chains: How U. S. Retailers Shape Overseas Production Networks", in G. Gereffi and. Korzeniewicz (eds.), Commodity Chains and Global Capitalism, London: Praeger.

[9] Hanson, D. K. and Mowen, M. M. (2000). Cost Management Accounting and Control; New Zealand; South-Western College Publishing.

[10] http://articles.timesofindia.indiatimes.com/2009-03-07/ahmedabad/28024544_1_kiln-bare-truthunorganised-sector

[11] http://laborrightsblog.typepad.com/international_labor_right/2012/03/historic-strike-of-brick-kilnworkers-in-andhra-pradesh-india.html

[12] http://www.indianexpress.com/news/study-points-to-lack-of-basic-facilities-for-brick-kilnworkers-in-gujarat

[13] Humphrey, J. and H. Schmitz, (2001), "Governance in Global Value Chains", in

[14] G.Gereffi and R. Kaplinsky (eds.), IDS Bulletin, Vol. 32, 3).

[15] Kaplinsky, Raphael. (2000) Globalisation and unequalisation: What can be learned from value chain analysis. The Journal of Development Studie.valume 37(2): pg. 117.

[16] Kaplinsky Raphael and Morris Mike (2000), A hand book for value chain.

[17] Maithel, Sameer et al. (2012). Brick Kilns Performance Assessment \& A Roadmap for Cleaner Brick Production in India.

[18] Nagaraj .B, Dr.Y. T. Krishnegowda.(2015).VALUECHAIN ANALYSIS FOR DERIVEDPRODUCTS FROM PADDY: A CASE OF KARNATAKA STATE. International Journal of Managing Value and Supply Chains (IJMVSC). Vol. 6. No.1.

[19] Nguyen Viet Khoi - Chu Huong Lan - To Linh Huong.(2015).VIETNAM TEA INDUSTRY: AN ANALYSIS FROM VALUE CHAIN APPROACH. International Journal of Managing Value and Supply Chains (IJMVSC). Vol. 6, No. 3.

[20] Panjab, Punjab State Council for Science \& Technology. (2010). Model Project

[21] Report for Setting up Energy Efficient Brick Kiln for the Production of Resource Efficient Bricks.

[22] Rajgor, Mamta B., Makwana, Ashish H and. Pitroda, Jayeshkumar . (2013). Automation in Clay and Thermal Industry Waste Products. International Journal of Engineering Trends and Technology. Volume4 (7):2870-2877.

[23] Saurav Negi, Neeraj Anand . (2015).ISSUES AND CHALLENGES IN THE SUPPLY CHAIN OF FRUITS \& VEGETABLES SECTOR IN INDIA: A REVIEW. International Journal of Managing Value and Supply Chains (IJMVSC). Vol. 6, No. 2.

[24] Schmitz, Hubert. (2005) .Value Chain Analysis for Policy-Makers and Practitioners

[25] Institute of Development Studies University of Sussex England.

[26] SG Acharyulu , K Venkata Subbaiah, K Narayana Rao .(2015).VALUE CHAIN MODEL FOR STEEL MANUFACTURING SECTOR: A CASE STUDY. International Journal of Managing Value and Supply Chains (IJMVSC). Vol. 6, No. 4.

[27] Sharma Deepak Kumar, Arun Varun, Patel Mansi.(2013). Qualitative study on clinic-social problem of brick kiln worker (2013): A study from Anad, Gujarat. National Journal of Community Medicine. Volume 4(3):503-506.

[28] S.Hemalatha, G. Ram Babu, K.Narayana Rao and K.Venkatasubbaiah .(2015).SUPPLY CHAIN STRATEGY BASED SUPPLIER EVALUATION-AN INTEGRATED FRAMEWORK. International Journal of Managing Value and Supply Chains (IJMVSC) .Vol. 6, No. 2.

[29] Siddharth Shankar Rai, Dr. Sunil Giri.(2015). BENCHMARKING THE SUPPLY CHAIN PERFORMANCE IN INDIAN GARMENT INDUSTRY. International Journal of Managing Value and Supply Chains (IJMVSC). Vol. 6, No. 2.

[30] Tara. (2012). Challenges \& Issues in the Indian Brick Sector. Retrieved from.

[31] http://www.ecobrick.in/challenges_Issues_in_the_Indian_Brick_Sector.aspx

[32] TBTMA. (2004).Report of the Second State Conference of Tamil Nadu Bricks and Tiles

[33] Manufacturers Association.

[34] UNDP-GEF. (2011). On Energy efficiency improvements in Indian brick industry, Approach paper on Market for Resource Efficient Brick products. 